\title{
Effect of Temperature and Pyrolysis Time in Liquid Smoke Production from Dried Water Hyacinth
}

\author{
Rita Dwi Ratnani ${ }^{1,4 *}$, Hadiyanto ${ }^{2,4}$ and Widiyanto ${ }^{3,4}$ \\ ${ }^{1}$ Chemical Engineering Department, Wahid Hasyim University, Semarang - Indonesia \\ ${ }^{2}$ Chemical Engineering Department, Diponegoro University, Semarang - Indonesia \\ ${ }^{3}$ Animal Husbandry Department, Diponegoro University, Semarang - Indonesia \\ ${ }^{4}$ School of Postgraduate Studies, Diponegoro University, Semarang - Indonesia
}

Received: 16/07/2020

Accepted: 22/10/2020

Published: 20/03/2020

\begin{abstract}
This study aimed to investigate the use of water hyacinth to produce liquid smoke. The study observes the temperature and time variables of yield, $\mathrm{pH}$, density, and refractive index in the production of liquid smoke from water hyacinth. The sequence of the work is as follows: first, water hyacinth was cut into $5 \mathrm{~cm}$ sections and then sun-dried for 2-3 d, depending on the weather. Next, $550 \mathrm{~g}$ of dried water hyacinth was added to the pyrolysis reactor. The temperature variations were $200^{\circ} \mathrm{C}, 400^{\circ} \mathrm{C}$, and $600^{\circ} \mathrm{C}$, and the time variations were 1,4 , and $7 \mathrm{~h}$. As a result, liquid smoke was produced with varying yield, $\mathrm{pH}$, densities, and refractive indices. The best results in this research are liquid smoke pyrolysis at a temperature of $400^{\circ} \mathrm{C}$ and $4 \mathrm{~h}$ with the acquisition of a yield of $93 \mathrm{~mL}, \mathrm{pH} 2-4$, a density of $1.080,8 \mathrm{gr} / \mathrm{mL}$, and a refractive index of $1.339,6$, with chemical component $41.45 \%$ total acid, $2.44 \%$ phenol and $56.10 \%$ carbonyl.
\end{abstract}

Keywords: Influence of temperature and time, liquid smoke, pyrolysis, water hyacinth

\section{Introduction}

A strategy that can be used to manage the lake ecosystem is the use of water hyacinth. The utilization of water hyacinth to create a product that is beneficial to Lake RawaPening is expected. RawaPening is currently dominated by water hyacinth (Eichornia crassipes), although it has a fairly high biodiversity. Water hyacinth grows at an increasing speed. Its distribution is expanding from year to year, thus resulting in the occurrence of sedimentation in RawaPening. This very high sedimentation rate has caused siltation in RawaPening. In 2020 Lake RawaPening is estimated to contain more than 4,752,961.04 tons of sediment. Sedimentation that occurred in Lake RawaPening as shown in Figure 1. The amount of sediment caused by the breeding of water hyacinth reached $187,839.45$ tons. The sedimentation rate in Lake RawaPening increased after 3 years. In 2008, the maximum depth of the swamp had reached $18.4 \mathrm{~m}$ around the Bukitcinta ecotourism. Based on the sedimentation rates, Lake RawaPening in 2017 only had a depth of around 5-8 m. With the effective efforts to control the breeding of water hyacinth which can be simulated in 2020, the depth will remain- However, if the breeding is not controlled, the sedimentation rate will continue to increase. It is estimated that Lake RawaPening Lake in 2020 will only have a depth of 2-5 m. With effective treatment, the spread of water hyacinth in Lake RawaPening will decrease, but will not be significant in 2020. The problem faced by Lake RawaPening is the rapid increase in sedimentation rate and growth of water hyacinth, which has an impact on the reduction of storage capacity and water quality. Some handling efforts that have been made have not shown significant results [1].

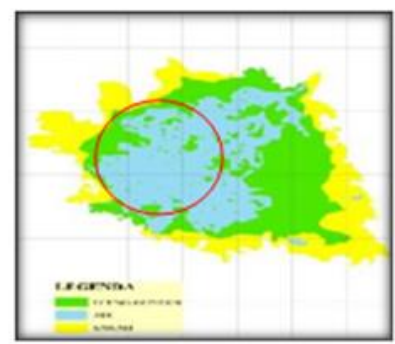

(a)

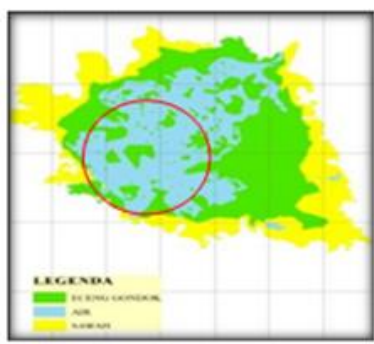

(b)
Figure 1. Simulation of the distribution of water hyacinth with control (a) and (b) without control in 2020 [2]

The process of water hyacinth pyrolysis takes place very quickly so that it can offset its growth. One alternative is to produce liquid smoke through pyrolysis. Pyrolysis is a "destructive distillation" or dry distillation process. It is an irregular decomposition process of organic materials caused by heating without contact with the outside air. During pyrolysis, heat energy induces oxidation, resulting in the breakdown of complex carbon molecules, mostly into carbon or charcoal. Pyrolysis is one of the thermochemical technologies. Converting

Corresponding author:_Rita Dwi Ratnani, (a) Chemical Engineering Department, Wahid Hasyim University, Semarang - Indonesia and (b) School of Postgraduate Studies, Diponegoro University, Semarang - Indonesia. E-mail: ritadwiratnani@unwahas.ac.id 
biomass into energy and chemical products consisting of liquid, biochar and gas $[2,3,4,5]$.

During pyrolysis, three types of products are produced: (1) The gases released in the carbonization process, which are mostly in the form of $\mathrm{CO}$ gas and partly in the form of flammable gases, such as $\mathrm{CO}, \mathrm{CH}_{4}, \mathrm{H}$, and other low-level hydrocarbons. (2) Distillate in the form of liquid smoke and tar. The main compositions of the product stored are methanol and acetic acid. The minor components include total phenol, methyl acetate, formic acid, butyric acid, and others. (3) Residue in the form of carbon. Wood has almost the same components and the pyrolysis process results in the decomposition of woods constituent compounds. The constituent compounds of liquid smoke are formed via pyrolysis of three wood components, namely, cellulose, hemicellulose, and lignin. These chemical components include (1) acids which can affect the taste, $\mathrm{pH}$, and shelf life of smoked products; (2) carbonyl which reacts with proteins and forms chocolate staining; and (3) phenols which mainly produce aroma and exhibit antioxidant activity $[6,7,8,9]$. Pyrolysis is the process of heating a substance without oxygen at temperatures above $150^{\circ} \mathrm{C}$. It is generally performed on wood. During the pyrolysis process, wood components decompose into hemicellulose, cellulose, and lignin. Based on the test results of the components of the wood constituents that have been carried out on water hyacinth and compared with other wood materials can be seen in Table 1. Pyrolysis produces substances, namely, charcoal, liquid smoke, and liquid gas. Liquid smoke formed by the hemicellulose pyrolysis process produces furfural, which is a furan derivative, as well as a long series of carboxylic acids, acetic acids, and homologues at temperatures of $200^{\circ} \mathrm{C}-250^{\circ} \mathrm{C}$. Pyrolysis of cellulose at a temperature of $280^{\circ} \mathrm{C}-320^{\circ} \mathrm{C}$ will produce acetic acid and a small amount of furan and phenol. Lignin pyrolysis produces phenols and phenol ethers at $400^{\circ} \mathrm{C}$. Liquid smoke is a liquid produced from condensation of wood smoke through the pyrolysis process. The components of liquid smoke containing acids can affect the taste, $\mathrm{pH}$, and shelf life of smoked products. The carbonyl component reacts with protein and turns into a chocolate color. The phenol component is the main constituent of aromas and exhibits antioxidant activity. In addition to acid, carbonyl, and phenol, liquid smoke also contains water, tar, and polycyclic aromatic hydrocarbons (PAH), such as benzo(a)pyrene, which are known as carcinogens, thus harmful to health [10, 11, 12]. This research aimed to produce liquid smoke from water hyacinth and examine the effect of temperature and time of pyrolysis on the quality of the resulting liquid smoke in terms of yield, $\mathrm{pH}$, density, and refractive index.

\section{Materials Methods \\ 2.1 Material Preparation}

The material used was water hyacinth obtained from Lake RawaPening, specifically at Rowoboni hamlet, Banyubiru District, Semarang. The stems of the water hyacinth were separated from their leaves and roots. Then, the stems were sun dried for 2-3 d until they turned brown. The water hyacinth stems were cut into $5 \mathrm{~cm}$ sections for ease of use during pyrolysis.
Table 1: Comparison of water hyacinth components with other Material

\begin{tabular}{|c|c|c|c|}
\hline \\
\hline No & Biomass type & $\begin{array}{l}\text { Chemical } \\
\text { components }\end{array}$ & $\%(\mathbf{d} . b)$ \\
\hline \multirow{3}{*}{1} & \multirow{3}{*}{ Water hyacinth } & Hemicellulose & 36.26 \\
\hline & & Cellulose & 20.64 \\
\hline & & Lignin & 7.32 \\
\hline \multirow{3}{*}{2} & \multirow{3}{*}{ Softwood } & Hemicellulose & $21-25$ \\
\hline & & Cellulose & $54-58$ \\
\hline & & Lignin & $26-29$ \\
\hline \multirow{3}{*}{3} & \multirow{3}{*}{ Hardwood } & Hemicellulose & $28-31$ \\
\hline & & Cellulose & $43-53$ \\
\hline & & Lignin & $18-24$ \\
\hline \multirow{3}{*}{4} & \multirow{3}{*}{ Coconut shell } & Hemicellulose & $5.26-20.54$ \\
\hline & & Cellulose & $28.26-32.52$ \\
\hline & & Lignin & $27.27-36.51$ \\
\hline \multirow{3}{*}{5} & \multirow{3}{*}{ Cassava stems } & Hemicellulose & $29.33-30.46$ \\
\hline & & Cellulose & $44.01-48.01$ \\
\hline & & Lignin & $15.39-15.98$ \\
\hline
\end{tabular}

\subsection{Pyrolysis Equipment}

Figure 2 presents the tools used for the pyrolysis process. Pyrolysis is performed in a reactor made of SS-304 plates that are $3 \mathrm{~mm}$ thick. The chancellor was designed so that it can carry 10 $\mathrm{kg}$ of dried water hyacinth stems cut into 5 -cm sections as much as $550 \mathrm{~g}$. because water hyacinth is very light so that the mass is sufficient for the process. The tool was connected to the condenser by a $1 / 4 \mathrm{SS}$ pipe. The condenser was equipped with a spiral pipe so that it can condense the smoke generated by the pyrolysis reactor. The length of the spiral pipe influences the yield of condensation. The longer the pipe, the longer the residence time in the condenser, so that the condensation process becomes more maximal. The length of the spiral pipe on this condenser is $3 \mathrm{~m}$. The heating process is performed using heater to reach the temperature of $600^{\circ} \mathrm{C}$. To maintain the desired temperature, a temperature control device was installed using a control valve so that a maximum temperature of $1000^{\circ} \mathrm{C}$ can be reached

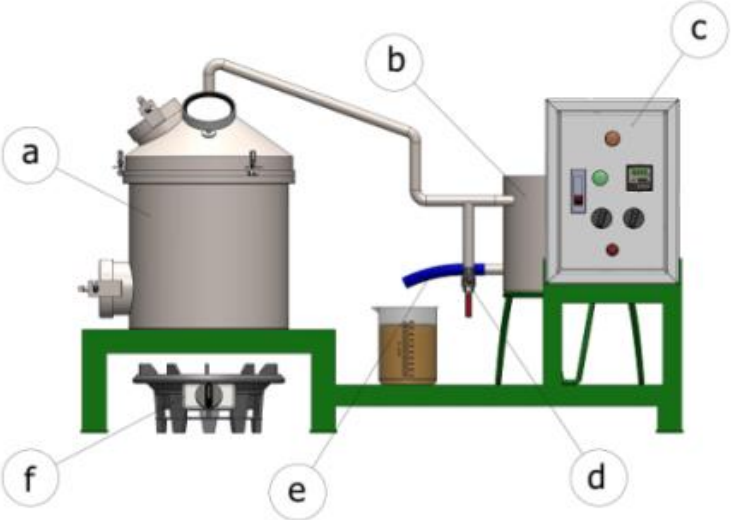

Figure 2: Equipment: (a) pyrolysis, (b) condenser, (c) valve control, (d) tar valve, (e) liquid smoke valve, and (f) heater

\subsection{Pyrolysis Water Hyacinth}

Water hyacinth was obtained from Lake RawaPening, and only the stem was taken. The stems were then cut into $5 \mathrm{~cm}$ sections and then sun dried until water content was around $15 \%$. 
The dried water hyacinth stem where then into the reactor pyrolysis as much as $550 \mathrm{~g}$. After adding all the ingredients, the pyrolysis reactor was covered so that no oxygen can enter. Subsequently, determine the temperature and time of the pyrolysis until the alarm sounds "check" on the control valve to the next heater ignited and the pyrolysis time was started. The temperature variations were $200^{\circ} \mathrm{C}, 400^{\circ} \mathrm{C}$, and $600^{\circ} \mathrm{C}$, and the time variations were 1,4 , and $7 \mathrm{~h}$, which were set using the control valve. By determining the temperature and time according to the research variable, the smoke generated during the pyrolysis process passed through a condenser which then change smoke into liquid. The resulting liquid was then collected in an Erlenmeyer, and the yield of the liquid smoke produced and the $\mathrm{pH}$, density, and refractive index were measured. More analysis of the chemical components produced via Gas Chromatography Mass Spectrometry (GCMS) was conducted

\subsection{Procedure of Analysis}

The liquid smoke produced by the pyrolysis process and its quality were then analyzed by looking at the parameters, such as the amount of the product, the degree of its acidity $(\mathrm{pH})$, its density, and its refractive index. Analysis was also conducted in order to determine the overall chemical component of the product via GCMS

\subsubsection{Yield Liquid Smoke}

The heating rate has a significant effect on product yield and distribution. The water hyacinth biomass pyrolysis product promises to produce valuable chemicals, fuels, and energy from renewable resources. Fast pyrolysis technology was chosen to maximize the yield of liquid products. The yield to liquid products can be as high as $75 \%$ (mass fraction with respect to the raw material fed in). This is characterized by a short residence time for solids and steam, a very high heating rate. The operating temperatures are usually in the range of $160^{\circ} \mathrm{C}-550^{\circ} \mathrm{C}$. However, there have been successful cases of fast pyrolysis technology utilization at a full scale, thus producing chemicals or energy [13, $14,15]$

\subsection{2 $\mathrm{pH}$ Value}

$\mathrm{pH}$ value is measured using a $\mathrm{pH}$ meter (Nutron Tech $\mathrm{PH}-$ 009-A Pen Type). Before its use, the $\mathrm{pH}$ meter is calibrated with a buffer solution. Measurement is performed by first dipping the electrodes into the distilled water and then wiping with tissue. Furthermore, the electrodes are inserted into the liquid smoke sample, and the $\mathrm{pH}$ value that appears on the screen is recorded. The acidity level or $\mathrm{pH}$ is measured to determine the acidity of the liquid smoke. The liquid smoke produced via pyrolysis is generally acidic, with a $\mathrm{pH}$ value in the range of $2-4$, mainly in the form of acetic acid and formic acid $[16,17,18]$.

\subsubsection{Determination of Density Liquid Smoke}

Determination of liquid smoke density using Pycnometer 10 $\mathrm{mL}$ brand Pyrex. The procedure for determining specific mass is as follows: (a) Pycnometer that is cleaned and dried is carefully weighed and its mass is recorded. (b) Insert the distilled water into the pycnometer until the calibration mark and its mass are recorded. (c) The distilled water was then discarded, and then the pycnometer was dried again. (d) Then liquid smoke is introduced into the pycnometer until the calibration mark and its mass are recorded. (e) The specific mass of liquid smoke is calculated using the show equation [19].

\subsubsection{Determination of Bias Index of Liquid Smoke}

The refractive index is determined using a refractometer (Optic Ivymen System Abbe). A refractometer is used as follows. First, it is cleaned with a tissue. Next, use a pipette to fill the space between the two prisms, such as distilled water or $5 \% \mathrm{NaCl}$ solution. Third, the refractometer is gently closed by returning the plate to its original position. Fourth, the number that appears on the screen is observed and then recorded. The usual index is the ratio of the speed of light in a vacuum to the speed of light in a substance. The refractive index of a substance is the measure of the speed of light in a liquid compared with when the substance is in the air. Measuring the refractive index enables the determination physical parameters, such as concentration, temperature, and pressure. Moreover, refractive index is measured to determine the purity level of the substance and its expiration $[20,21]$.

\subsubsection{GCMS Analysis}

The compound content of liquid smoke produced via pyrolysis is analyzed using Shimadzu GCMS-QP 2010S. Analysis used column type DB 624, length column 30 m, ID 0.25 $\mathrm{mm}, 0.25 \mu \mathrm{m}$ film. Detector is Ionization Polarity Positive, 70 electron scan range $40-400 \mathrm{~m} / \mathrm{z}$ (EI model). Helium as carrier gas is used. Its flow speed is set to $0.55 \mathrm{~mL} / \mathrm{min}$, injection is carried out for 1 minute at $250^{\circ} \mathrm{C}$. The programmed column temperature of $50^{\circ} \mathrm{C}$ is held for $5 \mathrm{~min}$, with an average increase of $5^{\circ} \mathrm{C}$ per minute to a temperature of $210^{\circ} \mathrm{C}$, which is then held for $13 \mathrm{~min}$. Liquid smoke is filtered through a filter paper and then injected into GCMS in the amount of $0.2 \mu \mathrm{L}$, so that it is chromatographed. Furthermore, the chromatogram peak's spectrum of the sample will be matched to the spectrum in the GCMS Library, which stores various types of compounds [22].

\section{Results}

\subsection{Effect of Temperature and Time Changes on Liquid Smoke Yield}

Figures 3. present the difference in liquid smoke in the temperature and time variations of the yield of liquid smoke produced, respectively. The Higher temperature and longer time of pyrolysis, the higher the increase of the resulting yield. This result is in line with those of previous studies. The best results were obtained at $600^{\circ} \mathrm{C}$, and within $7 \mathrm{~h}$, the yield was $119 \mathrm{~mL}$ of liquid smoke $/ 550 \mathrm{~g}$ of water hyacinth. At $400^{\circ} \mathrm{C}$ and within $7 \mathrm{~h}$, $115 \mathrm{~mL}$ of liquid smoke/550 $\mathrm{g}$ of water hyacinth was obtained. However, the high temperature and time can damage the tool and can thus make the obtained results insignificant, namely, $115 \mathrm{~mL}$ at $400^{\circ} \mathrm{C}$ and $119 \mathrm{~mL}$ at $600^{\circ} \mathrm{C}$ at $7 \mathrm{~h}$, as presented in Figure 3(a). Thus, the temperature of $400^{\circ} \mathrm{C}$ and $4 \mathrm{~h}$ are used as references in subsequent studies in which the yield was $93 \mathrm{~mL}$ of liquid smoke/550 g of water hyacinth, as described in Figure 3 (b). The results are almost the same as research conducted by several similar researchers [23,24, 25] 

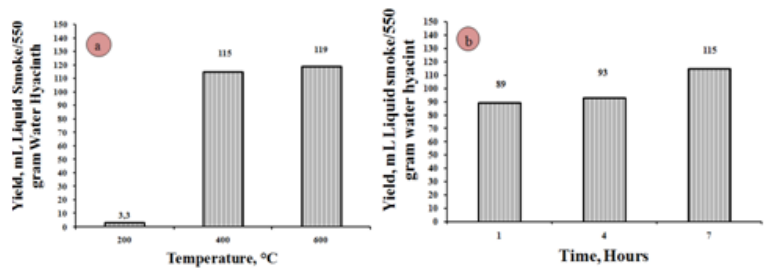

Figure 3: Effect of temperature (a) and time (b) on liquid smoke yield

\subsection{Effect of Temperature and Time on $\mathrm{pH}$}

Figures 4 the effect of temperature and time changes on $\mathrm{pH}$ of the liquid smoke produced $\mathrm{pH}$. The Measurement the liquid smoke of $\mathrm{pH}$ this research in the range $2-4$. The $\mathrm{pH}$ value indicates that the liquid smoke yield is acidic. The $\mathrm{pH}$ value will decrease with the increase in temperature and pyrolysis time. It is possible that more and more elements in the water hyacinth break down and form acidic chemical compounds. This acid content can also be observed via GCMS, in which it can be determined that the total acid contents produced at a temperature of $400^{\circ} \mathrm{C}$ for 1.4 and $7 \mathrm{~h}$ are $30.21 \%, 41.45 \%$, and $23.43 \%$. The acid component of $30.21 \%$ causes the $\mathrm{pH}$ of the liquid smoke results of this research to be at range $2-4$
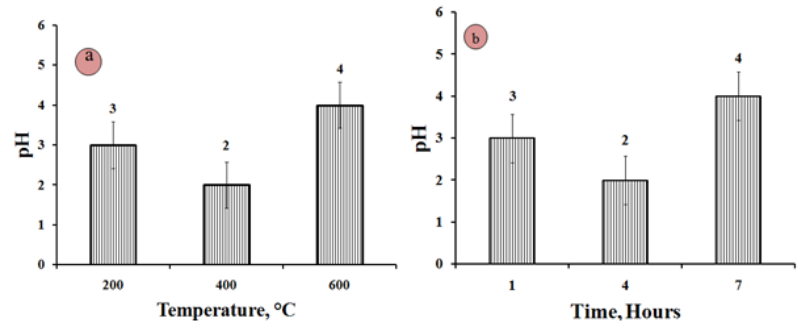

Figure 4: Change in temperature (a) and time (b) versus $\mathrm{pH}$

\subsection{Effects of Changes in Temperature and Time against Density}

The results of the study on the effect of temperature and time of pyrolysis on density are presented in Figures 5. The results indicate that if the temperature and time are high, then the density will decrease or smaller in the range of numbers 0.824-1.0875 $\mathrm{g} / \mathrm{mL}$ with $550 \mathrm{~g}$ of raw material. This shows that the density of liquid molecular bonds at higher temperatures results in smaller densities.
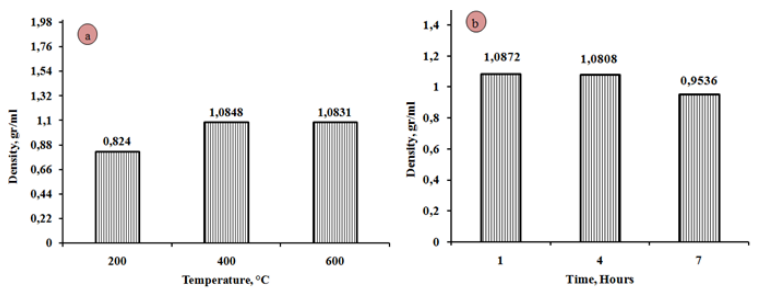

Figure 5: Effect of temperature (a) and time (b) changes on density

\subsection{Effects of Changes in Temperature and Time Against the Refractive Index}

Refractive index is the ratio between the speed of light which is an electromagnetic wave in a vacuum and the speed of light in a medium. The refractive index can also be used to determine the quality of a solution. Liquid smoke is golden yellow to dark brown in color. Light brown or a clear color is much preferred for food preservatives. The effect of temperature and time variations on the change in the refractive index can be seen in Figures 6 . The refractive index is measured using a refractometer. Refractive index testing is also performed to determine the level of purity. The refractive index of this research is in the range 1.342,2$1.347,0$ of the temperature variable. The time variable is in the range $1.339,5-1.341,9$. The highest refractive index were 1.347 at $200^{\circ} \mathrm{C}$ and 1.3419 at $400^{\circ} \mathrm{C}$ for $1 \mathrm{~h}$.
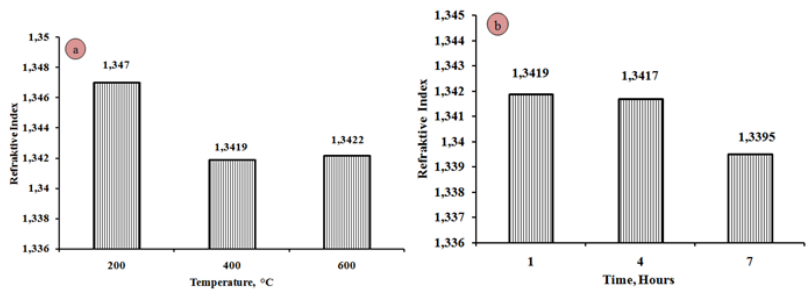

Figure 6: Changes in temperature (a) and time (b) against refractive index

\subsection{Observation of the Best Results via GCMS}

Chemical components were observed via GCMS. The best chemical component of dried water hyacinth smoke at $400^{\circ} \mathrm{C}$ for $4 \mathrm{~h}$ can be seen in Figure 7. The best liquid smoke yield obtained was $93 \mathrm{~mL} / 550 \mathrm{~g}$ of dried water hyacinth. Chemical components of water hyacinth liquid smoke through GCMS, obtained $41.45 \%$ total acid, $2.44 \%$ phenol, and $56.10 \%$ carbonyl as shown in Table 2. From Figure 7, the GCMS data show that the water hyacinth liquid smoke does not contain benzo(a)pyrene PAH, so it is safe to use as a food additive. This water hyacinth pyrolysis study gives results that are close to the pyrolysis process in coconut shells, palm oil starch waste, and durian waste as described in Table 2. In Table 2, the acquisition of phenol is different from that of the liquid smoke produced from oil palm empty fruit bunches, while the acid content is almost the same. An inversely proportional result is obtained by pyrolysis of the candlenut shell $[26,27]$.

Table 2: Comparison of acid, phenol, and carbonyl content of various raw materials

\begin{tabular}{llll}
\hline Ingredients & $\begin{array}{l}\text { Total acid } \\
(\%)\end{array}$ & $\begin{array}{l}\text { Total phenol } \\
(\%)\end{array}$ & $\begin{array}{l}\text { Carbonyl } \\
(\%)\end{array}$ \\
\hline Coconut shell & $39.57-58.76$ & $0.59-0.67$ & 3.71 \\
Empty fruit bunches & 44.70 & 30.68 & 12.37 \\
Cashew nuts & 18.8 & 36.6 & 7.1 \\
Candlenut shells & $3.65-7.87$ & $42.47-57,63$ & $34.5-53.88$ \\
Water hyacinth & 41.45 & 2.44 & 56.10 \\
\hline
\end{tabular}

In Figure 7 about observational data with GCMS, the peak components that exist are as shown in Table 3. The dominant chemical component is acetic acid as much as $41.45 \%$. The desired dominant peak liquid smoke water hyacinth has been reached, which contains acids in the form of acetic acid, butanoic acid which is at the peak 4-9 and 40. Other compounds expected from this study include phenols observed at peaks $33,38,44$, and 45. Carbonyl compounds are observed at peaks $10.11,12,21,34$, 
and 43 in the form of propanone, cyclopentane, furan, and pentanal. Figure 7 is marked with red, green and blue circles. The sign in red is acidic, blue is phenol and green is the sign for carbonyl.

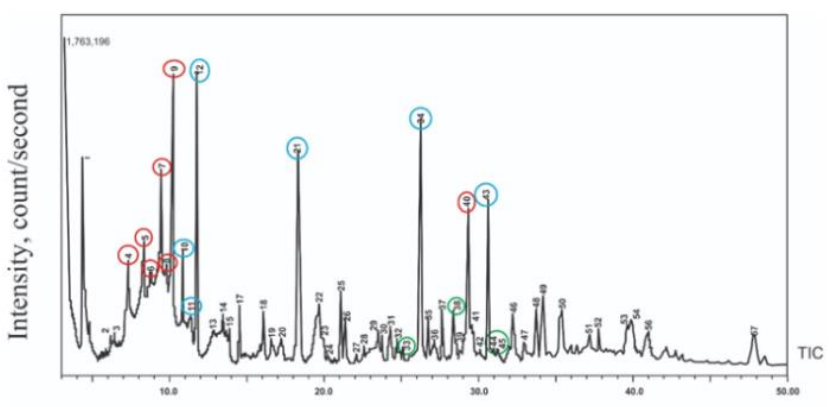

Time Retention, minute

Figure 7: Observations with GCMS

Table 3: Chemical composition of liquid water hyacinth smoke at $400^{\circ} \mathrm{C}$ for $4 \mathrm{~h}$

\begin{tabular}{clcclc}
\hline NO & \multicolumn{1}{c}{ Name } & \% AREA & NO & \multicolumn{1}{c}{ Name } & \% AREA \\
\hline 1 & Propanone & 5.19 & 29 & Furanone & 0.41 \\
2 & Acetic Acid & 0.22 & 30 & Furancarboxaldehyde & 0.23 \\
3 & Acetic Acid & 0.21 & 31 & Cyclopentene & 1.00 \\
4 & Acetic Acid & 3.62 & 32 & Hexadiene & 0.59 \\
5 & Acetic Acid & 5.50 & 33 & Phenol & 0.17 \\
6 & Formic acid & 5.43 & 34 & Cyclopentene & 4.55 \\
7 & Acetic Acid & 8.01 & 35 & Propanetriol & 0.64 \\
8 & Acetic Acid & 3.09 & 36 & Glycerin & 0.66 \\
9 & Acetic Acid & 7.37 & 37 & Propen-1-ol & 0.86 \\
10 & Propanone & 3.49 & 38 & Phenol & 1.58 \\
11 & Propanone & 1.53 & 39 & Cyclopentanone & 0.29 \\
12 & Propanone & 3.64 & 40 & Butanoic Acid & 4.20 \\
13 & Pyridine & 2.40 & 41 & Heptenal & 1.10 \\
14 & Ethanediol & 1.08 & 42 & Undecadiene & 0.49 \\
15 & 3-Penten-2-one & 0.69 & 43 & Pentanal & 2.85 \\
16 & Pyridine & 0.52 & 44 & Phenol & 0.31 \\
17 & Ethanediol & 0.69 & 45 & Phenol & 0.38 \\
18 & Cyclopentanone & 0.75 & 46 & Hexadiene & 1.77 \\
19 & Pyrazine & 0.65 & 47 & Butanol,Hexanol & 0.53 \\
20 & Butanoic Acid & 0.80 & 48 & Guanosine & 1.13 \\
21 & Furancarboxaldehyde & 5.57 & 49 & Propanoic Acid & 1.26 \\
22 & Furanmethanol & 3.51 & 50 & Benzenediol, & 1.57 \\
23 & Acetic Acid & 0.46 & 51 & Pentanedione & 0.68 \\
24 & Pyrazine & 0.18 & 52 & Benzenediol & 0.52 \\
25 & Cyclopentene & 1.27 & 53 & Benzenediol, & 0.97 \\
26 & Ethanone & 0.77 & 54 & Hydroperoxide & 1.58 \\
27 & Cyclopentene & 0.12 & 55 & Ethanol & 1.45 \\
28 & Cyclohexen & 0.18 & 56 & Hexanoic Acid & 1.28 \\
\hline Total & & & 99.99 & \\
\hline & & & & &
\end{tabular}

\section{Discussion}

In this research, the highest yield of liquid smoke was obtained at $600^{\circ} \mathrm{C}$ for $7 \mathrm{~h}$. This is because the higher the temperature and the longer the time of the water hyacinth pyrolysis, the more elements break down and condense into liquid smoke. It is also known that the liquid smoke making temperature is a determining factor in the yield of liquid smoke produced. The effect of pyrolysis temperature and time on the yield of liquid smoke indicates that the yield of liquid smoke products continues to increase along with the increase in pyrolysis time. When pyrolysis time increases, the condensation process runs longer, so that the smoke products will multiply. During pyrolysis, the decomposition process involves the breaking and forming of new bonds. Pyrolysis temperature affects the breakdown of the hydrocarbon chains from the polymer in the water hyacinth, so that the amount of liquid smoke produced will be different at each temperature increase. The increase in pyrolysis temperature causes the greater elements in the water hyacinth to decompose and condense into liquid smoke. Previous research also found a relationship between temperature and time of pyrolysis of liquid smoke products from sawdust producing yields that were almost similar to those obtained in this study which were $75 \mathrm{~mL}$, while this study was $93 \mathrm{~mL}$. The condensation process can work well. This is what causes all the smoke to form and convert to liquid smoke $[28,29,30]$.

Liquid smoke results of this research to be at range 2-4. The $\mathrm{pH}$ value indicates that the liquid smoke product is acidic. The $\mathrm{pH}$ value will decrease with the increase in temperature and pyrolysis time. This is due to the increasing number of elements in wood that break down and form acidic chemical compounds. The lowest $\mathrm{pH}$ value, which is 2.08 was observed in liquid smoke produced via pyrolysis at $350^{\circ} \mathrm{C}$ for $30 \mathrm{~min}$, indicating that in this operating condition numerous chemical compounds are acidic. Another study investigated the production of liquid smoke from organic waste, which produced at $\mathrm{pH}$ of 3.8-4.8 [31, 32, 33, 34].

Research conducted out in harmony with several other studies. Research by the best liquid smoke obtained from pyrolysis liquid smoke at $250^{\circ} \mathrm{C}$ for $90 \mathrm{~min}$, obtained liquid smoke with a pH value of 2.6 with a yield of $20.69 \%$ from the raw material $500 \mathrm{~g}$ of oil palm fronds with size $32-50$ mesh. The $\mathrm{pH}$ value of pyrolysis liquid also ranges from 2 to 3 due to the high amount of volatile acids, especially acetic acid and formic acid. This acid is produced via pyrolysis of hardwood, soft wood, and straw where it plays a role in tool corrosion $[35,36]$.

The temperature and time are high, then the density will decrease or smaller in the range of numbers $0.824-1.0875 \mathrm{~g} / \mathrm{mL}$ with $550 \mathrm{~g}$ of raw material water hyacinth. It is suspected that at high temperatures, the bonds between the compound molecules in the fluid will be far apart. The study was conducted on a walnut bark at a temperature of $300^{\circ} \mathrm{C}-700^{\circ} \mathrm{C}$ for $2.6 \mathrm{~s}$, and the density was found to be $0.0021 \mathrm{~g} / \mathrm{mL}$ with a raw material of $10 \mathrm{~g}$ [37].

Density is the ratio between the weight of a sample and its yield. In the physical properties of liquid smoke, density is not directly related to the high or low quality of liquid smoke. However, density can indicate the number of components in liquid smoke. The results of observations of the density of liquid smoke fraction over time ranged from $0.9536-1.8072 \mathrm{~g} / \mathrm{mL}$. The results were almost the same in the study of the effect of time on the density of liquid cinnamon smoke with a density of 1,017 $\mathrm{g} / \mathrm{mL}$

The density measurement data in previous studies also show results that are almost identical. The density of liquid smoke results from an increase in temperature although the increase is small. The highest density of liquid smoke ever obtained in liquid smoke products from coconut shells. The temperature of the pyrolysis process carried out was $350^{\circ} \mathrm{C}-450^{\circ} \mathrm{C}$, with a density gain between $1.086-1.101 \mathrm{~g} / \mathrm{mL}$. The results of this study support research on the acquisition of liquid smoke density from water hyacinth in the range $0.824-1.0875 \mathrm{~g} / \mathrm{mL}[19,38]$.

Refraction or refraction is an event of deflection in the direction of propagation of light because it passes through a medium based on differences in density. The ratio of the speed of light in a vacuum to the speed of light in a substance is called the refractive index. The refractive index of a substance is a measure of the speed of light in a liquid compared to that of a substance in 
air. Refractive index measurement in industry can be used to find physical parameters such as concentration, temperature and pressure. Refractive index can also be used to determine the quality of a solution. Refractive index testing is an important criterion that can be used to determine the purity of liquid smoke. The longer the carbon chain and the more double bonds, the greater the refractive index. Refractometer The most common is the Abbe (AR) Refractometer which is based on the principle of total reflection. The advantage of AR is high precision, and it can read refractive index values directly from the dial screen. The refractive index of liquid smoke from water hyacinth is in the range of $1.3395-1.3470$. The best results at a temperature of 400 and 1 hour were obtained 1.3419. The results are almost the same as the refractive index of liquid smoke from coconut shell and cinnamyl which was in the range $1.344-1.357$. The lowest refractive index is 1.344 , while the highest is liquid smoke residue of $1.673[19,39,40]$.

The total phenol content of liquid smoke does not depend on the moisture content of the raw material and the percentage of yield produced; rather, it highly depends on the chemical content characteristics of the raw material used and the temperature reached during the pyrolysis process. The content or phenol content of liquid smoke is influenced by the lignin content of the material and the pyrolysis temperature. Lignin is very stable and difficult to separate; it has also various forms, so it only decomposes at high temperatures. Lignin is basically a phenol that results from the breakdown of lignin in the pyrolysis process at $300^{\circ} \mathrm{C}-500^{\circ} \mathrm{C}$. Liquid smoke from water hyacinth contains a low phenol, which is equal to $2.44 \%$. In contrast to liquid smoke from cashew nut shells, the highest phenol in liquid smoke of cashew nuts is obtained at $400^{\circ} \mathrm{C}$ with total phenol of $36.6 \%$. Phenol content is influenced by lignin content in wood. The degradation of lignin to phenol occurs in two stages, namely, at an initial temperature of $300^{\circ} \mathrm{C}$, which causes breakdown of the phenol ring from lignin, and at temperatures of more than $300^{\circ} \mathrm{C}$, which results in polymerization to guaiacol (2-methoxyphenols), as well as other compounds, such as methanol, acetone, and acetic acid. Lignin decomposition results in the production of phenolic compounds. Cashew nut skin containing $16.42 \%$ lignin, while lignin in water hyacinth only $7.32 \%$. So, it is natural that the liquid phenol content of water hyacinth is lower than the liquid smoke phenol of cashew nuts [41, 42].

This observation is supported by the research conducted by [15], which suggests that liquid smoke formed via hemicellulose pyrolysis process produces furfural, a furan derivative, as well as a long series of carboxylic acids, acetic acids, and homologues at $200^{\circ} \mathrm{C}-250^{\circ} \mathrm{C}$. Cellulose pyrolysis produces acetic acid and its homologues and a small amount of furan and phenol at $280^{\circ} \mathrm{C}-$ $350^{\circ} \mathrm{C}$. Lignin pyrolysis produces phenols and phenol ethers at $400^{\circ} \mathrm{C}$

\section{Conclusion}

In this study, it can be concluded that temperature and time greatly affect the yield, $\mathrm{pH}$, density, and refractive index of the produced liquid smoke. Liquid smoke produced from water hyacinth plays a role in overcoming the rapid growth of water hyacinth in Lake RawaPening. It can help solve the environmental problems there. The best liquid smoke is obtained under the pyrolysis reactor operating condition of $400^{\circ} \mathrm{C}$ for $4 \mathrm{~h}$. The produced liquid smoke has $2.44 \%$ phenolic compound, which is very suitable for food preservation.

\section{Acknowledgment}

The author wishes to thank the Directorate General of Higher Education Republic of Indonesia Government, the Ministry of Education and Culture for providing scholarship support in conducting this research. We declare that there are no competing interests in this study. All authors of this study have a complete contribution for data collection, data analyses and manuscript writing.

\section{Ethical issue}

Authors are aware of, and comply with, best practice in publication ethics specifically with regard to authorship (avoidance of guest authorship), dual submission, manipulation of figures, competing interests and compliance with policies on research ethics. Authors adhere to publication requirements that submitted work is original and has not been published elsewhere in any language.

\section{Competing interests}

The authors declare that there is no conflict of interest that would prejudice the impartiality of this scientific work.

\section{Authors' contribution}

All authors of this study have a complete contribution for data collection, data analyses and manuscript writing.

\section{References}

1. Wulandari DA, Kurniani D, Edhisono S, Ardianto F, Dahlan D. The effect of small dams in RawaPening catchment area on sedimentation rate of RawaPening Lake.In Matec Web of Conferences;27-29 November 2018; Indonesia. Bandung p. 1-5.

2. Indrayati A, Hikmah NI. Prediction of Lake RawaPening Sediment in 2020 as a Basis for Reservation of Tuntang River Based on Geographic Information Systems in Proceedings of the UMS IX Geography National Seminar; River Restoration: Challenges and Solutions for Sustainable Development; 30 June 2018; Indonesia, Solo; p. 543-552.

3. Abdullah NA, Putra N, Hakim I, Koestoer RA. A Review of improvements to the liquid collection system used in the pyrolysis process for producing liquid smoke. International Jornal of Technology. 2017; 7: 1197-1206.

4. Czernik S, Bridgwater AV. Overview of Applications of biomass fast pyrolysis oil. Energy \& Fuels.2004; 18(12): 590-598.

5. Novita SA, Djinis ME, Melly S, Putri S.K. Processing Coconut fiber and shell to biodiesel. International Journal on Advanced Science Engineering Information Technology,.2014; 4(5): 84-86.

6. Gunnarsson CC, Petersen CM. Water hyacinths as a resource in agriculture and energy production: A literature review. Waste Manage. 2007; 2(27): 117-129.

7. Kan T, Strezov V, Evans, TJ. Lignocellulosic biomass pyrolysis: A review of product properties and effects of pyrolysis parameters. Renewable and Sustainable Energy Reviews. 2016; 57: 1126-1140.

8. Triastuti WE, Budhi PA, Agustiani E, Hidayat RA, Retnoningsih R, Nisa AA. Caracterization of liquid smoke bamboo waste with pyrolysis method. In. International Conference on Engineering, Advance Science and Industrial Application (ICETESIA); 6-7 September 2018; Indonesia, Surabaya. p. 114-117.

9. Wagiman FX, Ardiansyah A, Witjaksono W. Activity of coconutshell liquid-smoke as an insecticide on the rice brown planthopper (Nilaparvatalugens). ARPN Journal of Agricultural and Biological Science. 2014; 9(9):293-296.

10. Desniorita, Maryam. The effect of adding liquid smoke powder to shelf life of sauce. International Journal on Advanced Science, Engineering and Information Technology. 2015; 5(6): 457-459. 
11. Veksha A, Latiff, NM, Chen W, Ng JE, Lisak G. Heteroatom doped carbon nanosheets from waste tires as electrode materials for electrocatalytic oxygen reduction reaction: Effect of synthesis techniques on properties and activity. Carbon. 2020: 167: 104-113.

12. Verma R, Suthar S. Utility of duckweeds as source of biomass energy: a review. Bioenerg. Res. 2015; 8: 1589-1597.

13. Bimbela F, Abrego J, Gonzalo A, Sanchez JL, Arauzo, J. Biomass pyrolysis liquids Fundamentals, technologies and new strategies. Bol. Grupo Español Carbón.2014; 33: 11-14.

14. Ma H, Li T, Wu S. Zhang X. Effect of the interaction of phenolic hydroxyl with the benzene rings on lignin pyrolysis. Bioresource Technology. 2020; 309: 123351.

15. Yao, Z., Ma, X., \& Xiao, Z. The effect of two pretreatment levels on the pyrolysis characteristics of water hyacinth. Renewable Energy. 2020; 151:514-527.

16. Agblevor FA, Besler S, Evans RJ. Inorganic compounds in biomass feedstocks: their role in char formation and effect on the quality of fast pyrolysis oil. Biomass Pyrolysis Oil Properties and Combustion Meeting; 26-28 September 1994; Colorado, Estes Park. P. 77-89.

17. Demirbas MF, Balat, M. Biomass pyrolysis for liquid fuels and chemicals: A review. Journal of Scientific \& Industrial Research. 2007; 66:797-804.

18. Santos J, Ouadi M, Jahangiri H, Hornung A. Valorisation of lignocellulosic biomass investigating different pyrolysis temperatures. Journal of the Energy Institute. 2020; xxx (xxxx): $1-$ 10.

19. Lombok J, Setiaji B, Trisunaryati W. Wijaya K. Effect of pyrolisis temperature and distillation on character of coconut shell liquid smoke. Asian Jurnal of Science and Technology,.2014; 5(6):320 325 .

20. Oasmaa A, Leppämäki E, Koponen P, Levander J, Tapola E. Physical characterisation of biomass-based pyrolysis liquids application of standard fuel oil analyses; VTT Publications. 1997; p.22.

21. Witelski T, Bowen M. Methods of Mathematical Modelling. Springer Undergraduete Mathematic Series. 2015; p. 79

22. Jiu B, Li B, \& Yu Q. Effects of $\mathrm{Pb}$ on pyrolysis behavior of water hyacinth. Journal of Analytical and Applied Pyrolysis. 2015; 112:270-275.

23. Ifa L, Yani S, Mandasini M. et al. Production of phenol from liquid smoke resulted by the pyrolysis of cashew nut shells. In IOP Conference Series: Earth and Environmental Science, 25-26 October 2017; Indonesia, Makasar. p. 1-6.

24. Oasmaa A, Peacocke C. A guide to physical property characterisation of biomass-derived fast pyrolysis liquids. VTT Publications. 2001; p. 28

25. Ozbay G, Ayrilmis N. Effect of pyrolysis temperature on bio-oil production from vacuum pyrolysis of waste from wood industry. In Proceedings of 117th The IIER International Conference; 17-18 August 2017; Helsinki, Finland. p.56-58

26. Sulhatun S, Hasibuani R, Harahap H. Influence temperature of pyrolisis process on production of liquid smoke from candlenut shell by examining its potential coumpound. International Journal of Recent Technology and Engineering, 2019; 8(3):285-290.

27. Maulina S, Silia F. Liquid smoke characteristics from the pyrolysis of oil palm fronds. In IOP Conference Series: Materials Science and Engineering; 7-8 September 2017; Indonesia, Medan. p. 1-6.

28. Ramakrishnan S, Moeller P. Liquid smoke: Product of hardwood pyrolysis. Fuel Chem. Division Preprints. 2002; 47(1): 366-367.

29. Chowdhury ZZ, Yehye W, Pal K. Pyrolysis: A sustainable way to generate energy from waste. In TechOpen. 2017; p.23

30. Saloko S, Darmadji P, Setiaji B. Pranoto, Y. Antioxidative and antimicrobial activities of liquid smoke nanocapsules using chitosan and maltodextrin and its application on tuna fish preservation. Food Bioscience. 2014; 7: 71-79.

31. Berhimpon S, Montolalu RI, Dien HA., Mentang F Meko AUI. Concentration and application methods of liquid smoke for exotic smoked Skipjack (Katsuwonuspelamis L.). International Food Research Journal.2018; 25(1):864-1869
32. Parthasarathy P, Choi HS, Park HC, Hwang JG, Yoo HS, Lee BK, Upadhyay M. Influence of process conditions on product yield of waste tyre pyrolysis - A Review. Korean J. Chem. Eng. 2016; 33(8):2268-2286.

33. Swastawati F, Darmanto YS, Sya'rani L, Kuswanto, R, Taylor KDA. Quality characteristics of smoked Skipjack (Katsuwonuspelamis) using different liquid smoke. International Journal of Bioscience, Biochistry and Bioinformatics. 2014; 4(2): 94-99.

34. Zhang B, Zhong Z, Li T, Xue Z, Ruang R. Bio-oil production from sequential two-step microwave-assisted catalytic fast pyrolysis of water hyacinth using $\mathrm{Ce}$-doped $\gamma-\mathrm{Al}_{2} \mathrm{O}_{3} / \mathrm{ZrO}_{2}$ composite mesoporous catalyst. Journal of Analytical and Applied Pyrolysis. 2018; 132: 143150

35. Krisen SS, Setiaji B, Trisunaryanti, W, Pranowo HD. Intervention effect of liquid smoke of pyrolysis result of coconut shell on profile of $\mathrm{pH}$ fillet of lates calcarifer. In Proceeding of International Conference on Research, Implementation and Education of Mathematics and Sciences:18-20 May 2018; Indonesia Yogyakarta.p.18-20.

36. Montazeri N, Oliveira A C M. Himelbloom B H. Leigh M B, Crapo, C A. Chemical characterization of commercial liquid smoke products. Food Science \& Nutrition. 2012; 1(1):102-115.

37. Wang C, Luo Z, Li S, Zhu X. Coupling effect of condensing temperature and residence time on bio-oil component enrichment during the condensation of biomass pyrolysis vapors. Fuel. 2020; 274:117861.

38. Budaraga IK, Marlida Y, Bulanin U. Liquid Smoke production quality from raw materials variation and different pyrolysis temperature. International Journal on Advanced Science Engineering Information Technology. 2016; 6(3):306-315.

39. Worzakowska M, Scigalski P. Thermal behavior of cinnamyl diesters studied by the TG/FTIR/QMS in inert atmosphere. Journal of Analytical and Applied Pyrolysis. 2014; 106:48-56.

40. Yamasoe MA, Kaufman YJ, Dubovik O, Remer LA, Holben BN, Artakxo P. Retrieval of the real part of the refractive index of smoke particles from Sun/sky measurements during SCAR-B using spectral. Journal of Geophysical Research. 1998; 103:1-11.

41. Yusnaini, Y., Soeparrno, S., Suryanto, E., \& Armunanto, R. Physical, Chemical And Sensory Properties Of Kenari (Canariun Indicum L.) Shell Liquid Smoke Immersed Beef On Different Level Of Dilution. J.Indonesian Trop.Anim.Agric, 2012; 37(1):27-33.

42. Faisal M, Yelviasunarti AR, Desvita H. Characteristics of liquid smoke from the pyrolysis of durian peel waste at moderate temperatures. Rasayan J. Chem. 2018; 11(2):871-876.

43. Özbay G, Özçifçi, A, Kökten ES. The pyrolysis characteristics of wood waste containing different types of varnishes. Turk J Agric For. 2016; 40:705-714.

\section{Author Profile}

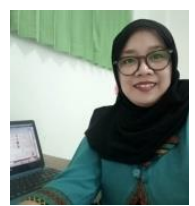

Rita Dwi Ratnani, ST., M.Eng Doctoral student at the Environmental Science Postgraduate School. Currently, Rita is a teaching staff at the Departement Chemical Engineering at Wahid Hasyim University with her expertise in waste management.

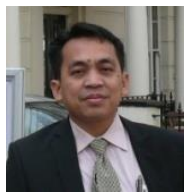

Prof. Dr. Hadiyanto, ST., M.Sc

Teaches at the Department of Chemical Engineering and the Environmental Science at the Postgraduate School of Diponegoro University. 


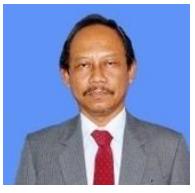

Prof. Dr. Ir. Widiyanto, SU

Teaches at the Department of

Animal Husbandry and the

Environmental Science

Doctoral Study Program at the

Postgraduate School of

Diponegoro University. 